\title{
Isolation and characterization of lactic acid bacteria and yeasts from the Brazilian grape sourdough
}

\author{
Krischina Singer Aplevicz ${ }^{1, *}$, Jaciara Zarpellon Mazo' $^{1}$, Eunice Cassanego Ilha', \\ Andréia Zilio Dinon ${ }^{3}$, Ernani Sebastião Sant'Anna²
}

\begin{abstract}
${ }^{1}$ Department Teaching, Research and Extension, Federal Institute of Santa Catarina, Florianopolis, SC, Brazil, ${ }^{2}$ Department of Food Science and Technology, Federal University of Santa Catarina, Florianopolis, SC, Brazil, ${ }^{3}$ Department of Engineering of Food, Staty University of Santa Catarina, Florianopolis, SC, Brazil
\end{abstract}

\begin{abstract}
Sourdough is a mixture of flour and water fermented by lactic acid bacteria and yeast, with a large use in bakery products. This study was developed with Brazilian grape (Niagara rosada) sourdough obtained from spontaneous fermentation. The aim of this work was to characterize genotypic and phenotypically lactic acid bacteria and yeasts isolated from sourdough. The phenotypic identification for bacteria and yeasts was performed by using the kit API50CHL and 20CAUX and the genotypic characterization was performed by sequencing method. A total of four isolated strains were analyzed in this study. Two of these strains were phenotypically and genotypic identified as Lactobacillus paracasei and one as Saccharomyces cerevisiae. Another sample phenotypically identified as Candida pelliculosa did not show the same identity by sequencing. It shows the need to use phenotypic and genotypic characterization associated for the correct microorganism identification.
\end{abstract}

Uniterms: Spontaneous fermentation. Sourdough. Brazilian grape/sourdough .Niagara rosada/sourdough. Lactic acid bacteria/phenotypic characterization. Lactic acid bacteria/genotypic characterization. Yeast/ phenotypic characterization. Yeast/ genotypic characterization.

Fermento natural é mistura de farinha e água fermentada por bactérias láticas e leveduras, amplamente utilizada em produtos de panificação. Neste estudo desenvolveu-se um fermento natural de uva brasileira (Niagara rosada), obtido a partir de fermentação espontânea. O objetivo deste trabalho foi caracterizar fenotipicamente e genotipicamente bactérias láticas e leveduras isoladas do fermento natural de uva. A identificação fenotípica para bactéria lática e leveduras foi realizada usando os kits API50CHL e 20CAUX e a caracterização genotípica foi realizada pelo método de sequenciamento. Neste estudo, isolaram-se quatro cepas. Duas cepas foram identificadas fenotipicamente e genotipicamente como Lactobacillus paracasei e outra cepa como Saccharomyces cerevisiae. A outra amostra de levedura, identificada fenotipicamente como Candida pelliculosa, não obteve a mesma identidade com a técnica de sequenciamento. Isso mostra a necessidade do uso da caracterização fenotípica e genotípica em associação para a correta identificação do micro-organismo.

Unitermos: Fermentação espontânea. Fermento natural. Uva brasileira/fermento natural. Niagara rosada/ fermento natural. Bactéria lática/caracterização fenotípica. Bactéria lática/caracterização genotípica. Levedura/caracterização fenotípica.Levedura/caracterização genotípica.

\section{INTRODUCTION}

Sourdough has a large application for bakery products, for examples the production of sourdough bread, classical bread, snacks, pizza and sweet baked products

*Correspondence: K. S. Aplevicz. Instituto Federal de Santa Catarina. Av. 15 de julho, 150,88075-0101 - Florianópolis, SC, Brasil. E-mail: aplevicz@gmail.com
(De Vuyst, Vancanneyt, 2007). Production of sourdough can be as simple as mixing flour and water and placing in a warm place. After several replenishments, the sourdough will be formed. The incorporation of sourdough in baking technological traits, enhances sensorial characteristics, increases shelf life and improves nutritional properties (Arendt, Ryan, Dal Bello, 2007; Corsetti et al., 2000). This positive impact of sourdough utilization is attributed 
to the microbiota that forms this unique ecosystem and consists of yeasts and lactic acid bacteria (Paramithiotis, Tsiasiotou, Drosinos, 2010).

Mostly yeasted pre-ferments are being used for the production of white bread. The use of lactic acid bacteria (LAB) as starter culture may help to improve the quality and shelf life of the products. The LAB from the sourdoughs naturally fermented may be used in the production of novel fermented foods such as sourdough bread, which is likely to have superior quality and long shelf life (Saeed et al., 2009). LAB belongs to a group of Gram positive bacteria, catalase-negative, non-motile, non-spore forming rods or coccid and produce lactic acid as the major end product during the fermentation. They are strictly fermentative, microaerofile, acidophilic, salt-tolerant with complex nutritional requirements for carbohydrates, amino acids, peptides, fatty acids, salts, nucleic acids derivatives and vitamins. The natural habitat of these microorganisms includes humans, animals and plants (Holzapfel et al., 2001). The LAB microbiota is predominant $(8 \log \mathrm{CFU} / \mathrm{g})$ and is represented, principally, by members of the genus Lactobacillus. Yeasts are generally counted in lower levels ( $7 \log \mathrm{CFU} / \mathrm{g})$ and can even be absent. The major part of the yeasts belong to the genera Saccharomyces and Candida (Vera et al., 2012).

Throughout Europe, Italy (Realeet al., 2011), Germany (Vogel et al., 1994) or Belgium (Scheirlincket al., 2007) sourdoughs have been studied intensively. Characterizations of Turkish (Gület al., 2005), Thai (Luangsakulet al., 2009), Chinese (Zhang et al., 2011) and French (Vera et al., 2012) sourdoughs have also been reported. However, research published in Brazil about sourdoughs is still scarce, even though the bread is widely consumed. The objective of this study was to develop a Brazilian grape sourdough and to identify genotypic and phenotypically four LAB and yeasts for further applications in breads.

\section{MATERIAL AND METHODS}

\section{Sourdough preparation}

Sourdough has been developed using Brazilian grape juice from "Niagara rosada" as substrate. The substrate was mixed with water and spontaneously fermented for 3 days at $25^{\circ} \mathrm{C}$ for the initial fermentation (IF). Thereafter, it was realized the first mixing with addition of $100 \%$ IF, $100 \%$ wheat flour, $10 \%$ of rye flour and $90 \%$ water, standing 24 hours at room temperature to origin the preferment. Following intervals of 24 hours, it was performed a second, a third and a fourth mixture using
$100 \%$ of preferment, $50 \%$ wheat flour, $10 \%$ of rye flour and $40 \%$ water. The sourdough remained for 8 hours at $25^{\circ} \mathrm{C}$, and 16 hours at $5{ }^{\circ} \mathrm{C}$ after each daily alimentation. The sourdough was refreshed regularly during one year.

\section{Isolation of lactic acid bacteria and yeast}

The counting of $\mathrm{LAB}$ and yeast was performed using the pour plate method. Aseptically, $25 \mathrm{~g}$ of sourdough

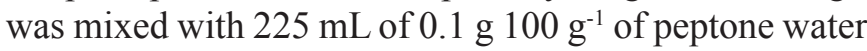
in BagMixer (model P, Interscience, St.Nom, France). From this dilution were realized subsequent necessary dilutions. The isolation of LAB was realized in MRS agar (Difco, Sparks,USA) with incubation at $3{ }^{\circ} \mathrm{C}$ under aerobiosis for $48 \mathrm{~h}$ and yeasts were grown in PDA Agar (Himedia, Mumbai, India) and tartaric acid 10\% under aerobic conditions at $25{ }^{\circ} \mathrm{C}$ for $72 \mathrm{~h}$. After incubation, isolated LAB colonies were randomly selected and were transferred to tubes containing MRS broth (Difco,Sparks, USA). Morphology was observed by Gram coloration and catalase test. Colonies isolated for yeasts growed in malt extract broth (Himedia, Mumbai, India) (Apha, 2001). The colonies were subjected to microscopic test to detect the presence of hyphae or pseudohyphae.

\section{Phenotypic characterization of LAB and yeast in sourdough}

The identification of lactic acid bacteria was done by phenotypic analysis using the kit API50CHL (BioMérieux, Marcy-1'Etoile, France) according Saeed et al.(2009) and Lu et al. (2008). The API 50CHL system allows the species identification of LAB according to the biochemical profile of carbohydrate fermentation. Readings were taken after 24 and 48 hours of incubation at $30^{\circ} \mathrm{C}$. The identification of yeasts was performed using the kit API 20CAux (BioMérieux, Marcy-l'Etoile, France) according Saeed et al.(2009) and the readings were made after 48 and 72 hours of incubation at $30^{\circ} \mathrm{C}$.

\section{Genotypic characterization of LAB and yeast in sourdough}

Two samples phenotypically characterized as LAB and two samples from yeasts were selected and sent for DNA sequencing at Genotyping Biotecnologia (Botucatu, São Paulo, Brazil). The genomic DNA of the isolates was extracted with $10 \%$ Chelex (Biorad, Hercules, CA), according manufacturer's protocol. The extracted genomic DNA was amplified by the universal $16 \mathrm{~S}$ primer (16S f AACGCGAAGAACCTAC 
and $16 \mathrm{~S}$ F $\mathrm{CGGTGTGTACAAGACC \text {) }}$ set for bacteria and with ITS primer (ITS 4 T C C T C C GCT TAT T GATAT and ITS 5 GGAAGTAAAAGTCTAACAAGG) set for fungi. PCR products were treated with ExoSAP-IT (USB, Ohio, USA) according to the manufacturer's instructions and directly sequenced with Applied Biosystems ${ }^{\circledR} 3500$ Genetic Analyzer (Foster City, CA). The nucleotide sequence of the sequencing products was determined by using the Sanger's chain termination method (Sanger, Nicklen, Coulson, 1977). The identity of the isolates was analyzed by using the Blast tool (Basic Local Alignment Search Tools Nucleotide) from the National Center for Biotechnology Information (NCBI).

\section{Statistical analysis}

All tests were performed in triplicate and the data expressed as mean \pm standard deviation. The genus and species of LAB and yeast isolated were interpreted by the statistical program APIWEB 50CHLv5.1 and APIWEB 20CAuxv 4.0, respectively.

\section{RESULTS AND DISCUSSION}

\section{Isolation of lactic acid bacteria and yeast}

The counting of aerobics $\mathrm{LAB}$ at $30^{\circ} \mathrm{C}$ was $7.52 \pm 0.07$ $\log \mathrm{CFU} / \mathrm{g}$ and yeasts was $7.62 \pm 0.29 \log \mathrm{CFU} / \mathrm{g}$. After incubation, 10 isolated $\mathrm{LAB}$ colonies were transferred to tubes containing MRS broth. A total of twenty-five colonies were isolated for yeasts and growed in malt extract broth.

\section{Phenotypic characteristics}

The results obtained by the isolates tested with
API 50CHL were shown in Table I. LAB samples 1 and 2 (Table I) of Lactobacillus paracasei (LAB samples 1 LAB obtained $6.36 \pm 0.18$ and LAB sample 2 obtained $8.34 \pm 0.15 \log \mathrm{CFU} / \mathrm{g}$ ) were selected to proceed this study due the high reliability of identification that was $99,5 \%$ and $99,9 \%$, respectively. Lactobacillus paracasei was the dominant species with $60 \%$ of identification among the LAB of Brazilian grape sourdough. The species Lactobacillus paracasei (LAB sample 1) achieved 99.5\% reliability of identification, while the Lactobacillus paracasei (LAB sample 2) showed 99.9\%. It proves that sourdough is more dominated by heterofermentative LAB in agreement with a previous study (De Vuyst, Neysens, 2005). Endo, Futagawa-Endo, Dicks (2011) reported that the carbohydrates have a big impact on the isolation of a variety of LAB in fermented food. It is observed in this study that after one year of sourdough cultivation, Lactobacillus brevis was the dominant species, with $70 \%$ of identification among $10 \mathrm{LAB}$ samples analyzed. Scheirlinck et al. (2009) indicated that specific strains of LAB persist in artisanal dough after many years and they circulate in the bakery environment. Furthermore, the air is a potential carrier of LAB in artisanal bakery environments.

Mugula, Narvhus, Sørhaug (2003) identified that starter cultures of LAB (Lactobacillus brevis, Lactobacillus cellobiosus, Lactobacillus fermentum, Lactobacillus plantarum and Pediococcus pentosaceus) and yeasts (Candida pelliculosa, Candida tropicalis, Issatchenkia orientalis and Saccharomyes cerevisiae) were isolated from native togwa.

The result of the fermentation of carbohydrates to yeasts is illustrated in Table II. The yeast samples selected for this study were samples 1 and2, both with $99.9 \%$ reliability of identification. Saccharomyces cerevisiae (yeast sample 1) and Candida pelliculosa

TABLE I - Phenotypic identification of lactic acid bacteria from Brazilian grape sourdough using API 50 CHL gallery kit

\begin{tabular}{lccccc}
\hline $\begin{array}{l}\text { Samples } \\
\text { LAB }\end{array}$ & Identification & $\begin{array}{c}\text { \% of reliability of } \\
\text { identification }\end{array}$ & Samples & $\begin{array}{c}\text { Identification after } \\
\text { 1 year }\end{array}$ & $\begin{array}{c}\text { \% of reliability of } \\
\text { identification }\end{array}$ \\
\hline 1 & Lactobacillus paracasei & 99.5 & 1 & Lactobacillus paracasei & 99.8 \\
2 & Lactobacillus paracasei & 99.9 & 2 & Lactobacillus brevis & 93.3 \\
3 & Lactobacillus brevis & 91.9 & 3 & Lactobacillus brevis & 95.8 \\
4 & Lactobacillus paracasei & 95.5 & 4 & Lactobacillus brevis & 98.3 \\
5 & Lactobacillus brevis & 95.5 & 5 & Lactobacillus paracasei & 99.1 \\
6 & Lactobacillus paracasei & 91.9 & 6 & Lactobacillus brevis & 91.6 \\
7 & - & Profile dubious & 7 & Lactobacillus brevis & 99.8 \\
8 & Lactobacillus delbrueckii & 95.6 & 8 & Lactobacillus brevis & 95.9 \\
9 & Lactobacillus paracasei & 95.5 & 9 & Lactobacillus brevis & 99.7 \\
10 & Lactobacillus paracasei & 99.1 & 10 & Lactobacillus delbrueckii & 92.5 \\
\hline
\end{tabular}


TABLE II - Yeasts isolated from brazilian grape sourdough identified by API 20CAux gallery kit

\begin{tabular}{|c|c|c|c|c|c|}
\hline $\begin{array}{l}\text { Samples } \\
\text { yeast }\end{array}$ & Identification & $\begin{array}{l}\% \text { of reliability of } \\
\text { identification }\end{array}$ & Samples & $\begin{array}{c}\text { Identification after } \\
1 \text { year }\end{array}$ & $\begin{array}{l}\% \text { of reliability of } \\
\text { identification }\end{array}$ \\
\hline 1 & Saccharomyces cerevisiae & 99.9 & 1 & Candida pelliculosa & 93.9 \\
\hline 2 & Candida pelliculosa & 99.9 & 2 & Saccharomyces cerevisiae & 99.9 \\
\hline 3 & Saccharomyces cerevisiae & 99.9 & 3 & Saccharomyces cerevisiae & 96.2 \\
\hline 4 & Saccharomyces cerevisiae & 96.2 & 4 & Candida guilliermondii & 89.9 \\
\hline 5 & Candida famata & 96.2 & 5 & - & Profile dubious \\
\hline 6 & Candidas phaerica & 98.5 & 6 & Saccharomyces cerevisiae & 99.9 \\
\hline 7 & - & Profile dubious & 7 & Candidasphaerica & 99.8 \\
\hline 8 & Candida pelliculosa & 88.8 & 8 & Candidasphaerica & 98.5 \\
\hline 9 & Saccharomyces cerevisiae & 96.2 & 9 & - & Profile dubious \\
\hline 10 & - & Profile dubious & 10 & - & Profile dubious \\
\hline 11 & Candida pelliculosa & 93.1 & 11 & Saccharomyces cerevisiae & 99.2 \\
\hline 12 & - & Profile dubious & 12 & Saccharomyces cerevisiae & 99.9 \\
\hline 13 & Candida pelliculosa & 99.3 & 13 & Saccharomyces cerevisiae & 99.7 \\
\hline 14 & Saccharomyces cerevisiae & 99.9 & 14 & Saccharomyces cerevisiae & 99.7 \\
\hline 15 & - & Profile dubious & 15 & Candida guilliermondii & 84.3 \\
\hline 16 & Candida pelliculosa & 93.1 & 16 & Candida pelliculosa & 99.8 \\
\hline 17 & Candida pelliculosa & 88.8 & 17 & Cryptococcus albidus & 99.8 \\
\hline 18 & Candida pelliculosa & 99.3 & 18 & Saccharomyces cerevisiae & 99.9 \\
\hline 19 & Candida pelliculosa & 99.9 & 19 & Saccharomyces cerevisiae & 99.9 \\
\hline 20 & Candida pelliculosa & 93.1 & 20 & - & Profile dubious \\
\hline 21 & Saccharomyces cerevisiae & 99.9 & 21 & Saccharomyces cerevisiae & 99.9 \\
\hline 22 & Candida pelliculosa & 88.8 & 22 & Saccharomyces cerevisiae & 99.7 \\
\hline 23 & Candida pelliculosa & 88.8 & 23 & Saccharomyces cerevisiae & 99.2 \\
\hline 24 & Saccharomyces cerevisiae & 99.9 & 24 & Saccharomyces cerevisiae & 99.9 \\
\hline 25 & Candida pelliculosa & 99.8 & 25 & Saccharomyces cerevisiae & 99.9 \\
\hline
\end{tabular}

(yeast sample 2) obtained $7.54 \pm 0.18$ and $7.34 \pm 0.06$ $\log \mathrm{CFU} / \mathrm{g}$, respectively. Candida pelliculosa was the dominant species with $48 \%$ of identification among yeasts isolated in Brazilian grape sourdough, followed by $28 \%$ of identification for Saccharomyces cerevisiae. Yeasts Candida famata and sphaerica showed $4 \%$ of identification. After one year of cultivation, it was observed that Saccharomyces cerevisiae was the dominant specie. Saccharomyces cerevisiae is the most common yeast used in bread making. Yeast cells metabolize fermentable sugars (glucose, fructose, sucrose and maltose) under anaerobic conditions producing carbon dioxide $\left(\mathrm{CO}_{2}\right)$ as a residual product, which acts as a leavening agent and enhances dough volume (Chavan, Jana, 2008; Giannou, Kessoglou, Tzia, 2003). Rosenquist and Hansen (2000) reported that Saccharomyces cerevisiae was the yeast specie isolated only from sourdoughs.
Lu et al. (2008) isolated and characterized phenotypically 170 LAB and 96 yeasts in sour Mifen, a traditional fermented rice noodle from China. Lactobacillus plantarum and Saccharomyces cerevisiae were identified as predominant. The microflora of twenty five wheat sourdoughs from the Apulia region, southern Italy, was characterized for Corsetti et al. (2001). Edema and Sanni (2008) reported that for sour maize bread, $30 \%$ of the isolates were identified as Lactobacillus sanfranciscensis, $20 \%$ as Lactobacillus alimentarius, $14 \%$ as Lactobacillus brevis, $12 \%$ as Leuconostoc citreum, $7 \%$ as Lactobacillus plantarum, $6 \%$ as Lactococcus lactis subsp. lactis, $4 \%$ as Lactobacillus fermentum and Lactobacillus acidophilus, $2 \%$ as Weissella confuse and $1 \%$ as Lactobacillus delbrueckii subsp. delbrueckii.

Qureshi, Masud, Sammi (2007) isolated and characterized yeast strains on the basis of the capacity to use maltose during bread fermentation. From these 
TABLE III - Genotypic identification of lactic acid bacteria and yeasts isolated from Brazilian grape sourdough

\begin{tabular}{lccl}
\hline Samples & $\begin{array}{c}\text { Sequence } \\
\text { coverage }\end{array}$ & $\begin{array}{c}\text { Percent of } \\
\text { identity }\end{array}$ & Genotypic identity \\
\hline Lactobacillus paracasei (LAB 1) & $93 \%$ & $99 \%$ & Lactobacillus casei, L. rhamnosus and L. paracasei \\
Lactobacillus paracasei (LAB 2) & $97 \%$ & $98 \%$ & Lactobacillus casei, L. rhamnosus and L. paracasei \\
Saccharomyces cerevisiae (yeast 1) & $93 \%$ & $88 \%$ & Saccharomyces cerevisiae \\
Candida pelliculosa (yeast 2) & $89 \%$ & $99 \%$ & Saccharomyces cerevisiae \\
\hline
\end{tabular}

40 strains, 14 were identified as $S$. cerevisiae, 12 as S.kluyveri, 4 as S. exigus and S. dairnensis, 2 as S. ludwigii, $S$. octosporusand $S$. unisporus, respectively. Later on, 14 isolates of $S$. cerevisiae were assessed for their maltose utilization capacity for bread production.

\section{Genotypic identification}

Four representative LAB cultures and yeasts phenotypically characterized in this study were genotypically analyzed by sequencing of $16 \mathrm{~S}$ rRNA region for LAB and ITS for fungi detection. The sequencing product resulted in a main amplicon of $600 \mathrm{bp}$ for LAB samples and $800 \mathrm{bp}$ for yeasts samples. The result of the genotypic identification is illustrated in Table III.

The sample phenotypically characterized as Lactobacillus paracasei (LAB sample 1) showed 93\% of sequence coverage with $99 \%$ of identity for Lactobacillus casei, L. rhamnosus and L. paracasei. The isolated culture phenotypically identified as Lactobacillus paracasei (LAB sample 2) showed $97 \%$ of sequence coverage with $98 \%$ of identity for Lactobacillus casei, L. rhamnosus and L. paracasei.

The partial sequence results for one of the isolated culture phenotypically characterized as Saccharomyces cerevisiae (yeast sample 1) obtained $88 \%$ percent of identity for Saccharomyces cerevisiae with $93 \%$ of sequence coverage. The isolated culture phenotypically identified as Candida pelliculosa (yeast sample 2) showed 99\% percent of identity for Saccharomyces cerevisiae with $89 \%$ of sequence coverage.

These sequence results suggested that all LAB samples showed major identity with Lactobacillus casei, L. rhamnosus and L. paracasei. Moreover, the phenotypic characterization suggested that LAB samples were $L$. paracasei.

According to the phenotypic and genotypic results for yeast samples, it was possible to confirm the identification of Saccharomyces cerevisiae for yeast sample 1. Therefore, yeast sample 2 showed phenotypic identification as Candida pelliculosa and genotypic identification as
Saccharomyces cerevisiae. Compared with PCR, the phenotypic characterization by carbohydrates fermentation is less sensitive due to natural variations in this process (Barros et al., 2009). According to Nigatu (2000), main differences between genotypic and phenotypic analysis suggested that results from API kit should be complemented with genetic results to give an accurate result.

\section{CONCLUSION}

This study allowed to isolate and to identify four microorganisms in Brazilian grape sourdough with technological potential for sourdough applications. The phenotypic and genotypic characterization suggested that two samples were Lactobacillus paracasei and one sample is Saccharomyce cerevisiae. One sample phenotypically identified as Candida pelliculosa was genotypic identified as Saccharomyces cerevisiae. It suggests that phenotypic results should be confirmed by genotypic analysis.

\section{ACKNOWLEDGEMENTS}

This work was financially supported by National Council for Scientific and Technological Development, CNPq, Brazil.

\section{REFERENCES}

AMERICAN Public Health Association. Compendium of methods of the microbiological examination of foods.4.ed. APHA: Washington, 2001.

ARENDT, E.K.; RYAN, L.A.M.; DAL BELLO, F. Impact of sourdough on the texture of bread. Food Microbiol., v.24, p.165-174, 2007.

BARROS, M.R.; ANDREATTI FILHO, R.L.; OLIVEIRA, D.E.; LIMA, E.T.; CROCCI A.J.Comparação entre método bioquímico e reação em cadeia de polimerase para identificação de Lactobacillus spp. isolados de aves. Arq. Bras. Med. Vet. Zootec.,v.61, p.319-325, 2009. 
CHAVAN, R.S.; JANA, A. Frozen dough for bread making - a review.Int. J. Food Sci. Technol. Nutr., v.2, p.9-27, 2008.

CORSETTI, A.; GOBBETTI, M.; DE MARCO, B.; BALESTRIERI, F.; PAOLETTI, F.; RUSSI, L.; ROSSI, J. Combined effect of sourdough lactic acid bacteria and additives on bread firmness and staling. J. Agric. Food Chem.,v.48,p.3044-3051, 2000.

CORSETTI, A., LAVERMICOCCA, P.; MOREA, M.; BARUZZI, F.; TOSTI, N.; GOBBETTI, M. Phenotypic and molecular identification and clustering of lactic acid bacteria and yeasts from wheat (species Triticum durum and Triticumaestivum) sourdough of southern Italy. Int. J. Food Microbiol., v.64, p.95-104, 2001.

DE VUYST, L.; NEYSENS, P.The sourdough microflora: biodiversity and metabolic interactions. Trends Food Sci. Technol., v.16, p.43-56, 2005.

DE VUYST, L.; VANCANNEYT, M. Biodiversity and identification of sourdough lactic acid bacteria. Food Microbiol., v.24, p.120-127, 2007.

EDEMA, M.O.; SANNI, A.I. Functional properties of selected starter cultures for sour maize bread. Food Microbiol., v.25, p.616-625, 2008.

ENDO, A.; FUTAGAWA-ENDO, Y.; DICKS, L.M.T. Influence of carbohydrates on the isolation of lactic acid bacteria. $J$. Appl. Microbiol., v.110, p.1085-1092, 2011.

GIANNOU, V.; KESSOGLOU, V.; TZIA, C. Quality and safety characteristics of bread made from frozen dough. Trends Food Sci. Technol., v.14, p.99-108, 2003.

GÜL, H.; ÖZÇELIK, S.; SAGDIÇ, O.; CERTEL, M. Sourdough bread production with lactobacilli and $S$. cerevisiae isolated from sourdoughs. Process Biochem., v.40, p.691-697, 2005.

HOLZAPFEL, W.H.; HABERER, P.; GEISEN, R.; BJORKROTH, J.; SCHILLINGER, U. Taxonomy and important features of probiotic microorganisms in food and nutrition. Am. J. Clin. Nutr.,v.73, p.365-373, 2001.

LU, Z.H.; PENG, H.H.; CAO, W.; TATSUMI, E.; LI, L.T. Isolation, characterization and identification of lactic acid bacteria and yeasts from sour Mifen, a traditional fermented rice noodle from China. J. Appl. Microbiol., v.105, p.893903, 2008.
LUANGSAKUL, N.; KEERATIPIBUL, S.; JINDAMORAKOT, S.; TANASUPAWAT, S. Lactic acid bacteria and yeasts isolated from the starter doughs for Chinese steamed buns in Thailand. Food Sci. Technol., v.42, p.1404-1412, 2009.

MUGULA, J.K.; NARVHUS, J.A.; SØRHAUG, T. Use of starter cultures of lactic acid bacteria and yeasts in the preparation of togwa, a Tanzanian fermented food. Int. J. Food Microbiol., v.83, p.307-318, 2003.

NIGATU, A. Evaluation of numerical analyses of RAPD and API $50 \mathrm{CH}$ patterns to differentiate Lactobacillus plantarum, Lact. fermentum, Lact. rhamnosus, Lact. sake, Lact. Parabuchneri,Lact. gallinarum, Lact. casei, Weissella minor and related taxa isolated from kocho and tef. J. Appl. Microbiol., v.89, p.969-978, 2000.

PARAMITHIOTIS, S.; TSIASIOTOU, S.; DROSINOS, E.H. Comparative study of spontaneously fermented sourdoughs originating from two regions of Greece: Peloponnesus and Thessaly. Eur. Food Res. Technol., v.231, p.883-890, 2010.

QURESHI, S.K.; MASUD, T.; SAMMI, S. Isolation and taxonomic characterization of yeast strains on the basis of maltose utilization capacity for bread making. Int. J. Agric. Biol., v.9, p.110-113, 2007.

REALE, A.; DI RENZO, T.; SUCCI, M.; TREMONTE, P.; COPPOLA, R.; SORRENTINO, E. Identification of lactobacilli isolated in traditional ripe wheat sourdoughs by using molecular methods. World J. Microbiol.Biotechnol., v.27, p.237-244, 2011.

ROSENQUIST, H.; HANSEN, A. The microbial stability of two bakery sourdoughs made from conventionally and organically grown rye. Food Microbiol., v.17, p.241-250, 2000.

SAEED, M.; ANJUM, F.M; ZAHOOR, T.; NAWAZ, H.; REHMAN, S.U. Isolation and characterization of starter culture from spontaneous fermentation of sourdough. Int. J. Agric. Biol., v.11, p.329-332, 2009.

SANGER, F., NICKLEN, S. COULSON, A.R. DNA sequencing with chain-terminating inhibitors. Proc. Natl. Acad. Sci., v.74, p.5463-5467, 1977. 
SCHEIRLINCK, I.; VAN DER MEULEN, R.; DE VUYST, L.; VANDAMME, P.; HUYS, G. Molecular source tracking of predominant lactic acid bacteria in traditional Belgian sourdoughs and their production environments. J. Appl. Microbiol., v.106, p.1081-1092, 2009.

SCHEIRLINCK I.; VAN DER MEULEN, R.; VAN SCHOOR, A.; VANCANNEYT, M.; DE VUYST, L.; VANDAMME, P.; HUYS, G. Influence of geographical origin and flour type on diversity of lactic acid bacteria in traditional Belgian sourdoughs. Appl. Environ. Microbiol.,v.73, p.6262-6269, 2007.

VERA, A.; LY-CHATAIN, M.H.; RIGOBELLO, V.; DEMARIGNY, Y. Description of a French natural wheat sourdough over 10 consecutive days focussing on the lactobacilli present in the microbiota. Antonie van Leeuwenhoek, v.101, p.369-377, 2012.
VOGEL, R.F.; BÖCKER, G.; STOLZ, P.; EHRMANN, M.; FANTA, D.; LUDWIG, W.; POT, B.; KERSTERS, K.; SCHLEIFER, K.H.; HAMMES, W.P. Identification of lactobacilli from sourdough and description of Lactobacillus pontis sp. nov. Int. J. Syst. Bacteriol., v.44, p.223-229, 1994.

ZHANG, J.; LIU, W.; SUN, Z.; BAO, Q.; WANG, F.; YU, J.; CHEN, W.; ZHANG, H. Diversity of lactic acid bacteria and yeasts in traditional sourdoughs collected from western region in Inner Mongolia of China. Food Control., v.22, p.767-774, 2011.

Received for publication on $13^{\text {th }}$ May 2013 Accepted for publication on $15^{\text {th }}$ August 2013 
